\title{
Using m-Learning as an Effective Device in Teaching and Learning in Higher Education in Saudi Arabia
}

\author{
Salem Alkhalaf, Mohammed Amasha, and Amal Al-Jarallah
}

\begin{abstract}
E-learning is the use of technology to enable students to learn at anytime and anywhere. E-learning might also include the provision of information, and training in a timely manner, as well as guidance from experts. Technology can effectively enable learners to learn at any place and any time. Mobile learning or m-learning is defined as Learning through multiple channels, using smart devices, through social networking and content. Mobile devices such as mobile phones, PDAs, and tablets such as iPads are popular and attractive among consumers due to several factors. In Saudi Arabia, universities have explored the implementation of m-learning devices to support learning and teaching. The purpose of this qualitative research was to examine students' attitudes towards the use of m-learning for teaching and learning in Saudi Arabia. A questionnaire was designed with three pivots distributed across 20 questions, and was distributed to 93 students who were selected randomly from Nora University, Qassim University, and King Abdul-Aziz University. Chi-Square $\left(x^{2}\right)$ was used to analyse data for comparison between frequencies (f) and expected frequencies (fe) around the phrases of the questionnaire. The results showed that students learnt a lot through the presence of m-learning. M-learning enhanced their awareness and recall of job-related information. However, they indicated that information from $\mathrm{m}$-learning should be in a form that is readily usable. The students also confirmed that the quality of m-learning system was satisfactory.
\end{abstract}

Index Terms-Mobile learning, teaching, learning, Saudi Arabia.

\section{LITERATURE REVIEW}

\section{A. Mobile Learning}

\section{1) Background}

The use of mobile devices in learning is a new technological development in learning institutions. This is true in consideration of not only student development but also teacher development. The use of mobile phones has also been seen to have a significant position in the lives of most youths. This explains why there have been growing changes in the field of mobile technology. The integration of mobile learning in the education of teachers has become a trending issue, but with very few instances of relevant theories and concepts being identified. However, the use of mobile learning in institutions depends largely on the attitude, perceptions, and patterns with which it is used by teachers and students. The

Manuscript received December 12, 2015; revised March 18, 2016

Salem Alkhalaf and Mohammed Amasha are with Computer Department, College of Science and Arts, Qassim University, Alrass City, Qassim, KSA (e-mail: s.alkhalaf@qu.edu.sa,mw.amasha@yahoo.com)

Amal Al-Jarallah is with Prince Norah University, Canada (e-mail: asaljarallah@pnu.edu.sa). use of mobile learning is also seen as an additional advantage to institutions that implement it, since challenges are not commonly experienced. For these and other reasons, the adoption of mobile learning by teachers includes the use of programs and various development techniques that enable the integration of mobile learning knowledge with the preferences of teachers and of course objectives [1]. Technologies aimed at mobile learning are more likely to greatly impact the level of efficiency in the learning process. This has led to most learning institutions adopting mobile technologies in various fields of learning activities. The great challenge involved herein is a lack of awareness and poor knowledge of how mobile technologies hinder complete integration of these devices in a learning environment [2].

\section{2) Definition}

Mobile learning is a technological innovation that makes it possible for students and teachers to use mobile devices in the education system. Through mobile technology, communication in the education sector has improved due to the wider scope of learning. Mobile learning also refers to learning through cell phones, since this is the major device used for learning. Mobile learning can only take place if all necessary materials are available. For instance, there must be portable enough devices for every individual at all times and at all places. Such devices must also be in different forms that suit the best interests of the users in terms of settings, lifestyle suitability, and market pricing. Some of the mobile devices used in mobile learning include the following: the ability to connect to GPRS, cell phones, laptops, smart phones, wireless technologies, notebooks, and Bluetooth devices.

The process of mobile learning is a long-term one, since the desired results are not readily achievable. It also requires the guidance of a management team that will ensure that learners gain more from the use of mobiles and other practices that evolve with time. Kaganer [3] shows that students are more at ease when it comes to the use of tablet and iPads but experience a lot of difficulties in using them for learning and collaborative purposes. He also shows that there must be a close relationship between the design of courses and the functionality of mobile devices intended for course use in order for mobile learning to be successful.

\section{3) Importance of mobile learning in education}

Mobile technologies like cell phones, laptops, and pocket computers have led to the evolution of the learning environment by transforming traditional teaching, where both teachers and students had to be present in class. Unlike the traditional presence mode of teaching and learning, mobile learning enables learners to make good use of time and money. This is possible with reduced travel costs since accessibility is 
everywhere, whether one is at home, in the office, or at school. Similarly, mobile learning enables students to utilize every available minute to conduct research. For instance, online classes can be done in the midst of a traffic jam, or at a bus stop. Mobile learning also enables teachers to reach out to students in different countries using hot spot domains without the need to physically relocate to those countries or move to an area with internet-connected gadgets before they get to teach. Nordin and his friends view mobile learning as a quest for learning opportunities that translate to sharing with others. Mobile teaching also enables learners to receive the content of courses through their cell phones, whether in their homes or on a road trip, through the use of Wikipedia, blog websites, and other networks for social activities. Mobile learning is also said to reduce geographical boundaries and increase social interactions among teachers, students, and between teachers and students. This wide geographical interaction encourages cooperation among students and provides opportunities for students to accomplish both individual and group tasks in learning and training environments. Another outstanding feature of mobile learning is immediacy. It is a faster and simpler way of learning than any other mode of study. This is due to the fact that it encourages more immediate and spontaneous responses from both teachers and learners. Additionally, mobile learning has led to a consistently increasing flexibility and has also encouraged freedom of expression by students, since they must constantly teach themselves better ways to interact via virtual means. The advancement in learning technology also enables learners to use multimedia services in their cell phones by installing applications that necessitate quick access to a wide range of learning resources [4].

The use of mobile learning in education and teaching (with examples)

Different learning institutions have adopted different methods of mobile learning. For instance, some colleges use distance learning online modules, tablets which are widely used as notebooks, and other devices. One such system that supports the use of these resources is a reality-based mobile learning system. This system is used to carry out research on activities based on inquiries. An experiment was conducted by Chiang, Yang, \& Hwang in 2014 on reality-based mobile learning systems. This system was first tested in an elementary school in Taiwan where one teacher was made to teach 57 students from two different classes. The aim of this experiment was to determine how effective the system is when it comes to achievement motivation and learning by students. The outcome was positive and the system was found to be capable of improving learning and motivation in students. Further discoveries showed that such students were motivated to have confidence, become attentive, and seek other dimensions of life, which were much relevant to learning [5].

Another way of conducting mobile learning is by using an axiomatic approach. This is a method based on the use of well-designed tools and processes. A system is assembled to match the functionality necessities of the instructional program. It revolves around the development of mobile computing programs and portable programs that are used for training. This approach also ensures the development of applications and software that enable the easy connection of instructors, practitioners, and learners [6]. It also enables learning in a collaborative manner from a wide range of mobile devices from a global standpoint. This approach also aims at incorporating all the necessary apps, systems, and content development that will ensure connectivity to physical and non-physical surroundings. This is geared towards making mobile learning a more interesting approach to modern learning [7].

Another approach to mobile learning is the use of tools embedded in cloud technology. In this approach, mobile learning is treated as a part or rather an extension of electronic learning technologies. Such a system is expensive to develop and thus requires a lot of 'pedagogical principles' and attention to details at both the design and implementation stages of system development. Unique and specific strategies must be employed to achieve an enabling system. This is a system that ensures an effective learning outcome since it enables evaluation of processes and a model that evaluates the interactive nature and feedback of content from students and teachers alike [8], [9].

\section{LEARNING MANAGEMENT SySTEMS}

\section{A. Background}

In the recent past, learners and educators have remained focused on making the learning process an easy and interesting process. In doing so, many inventions have come up that have aimed to do away with traditional learning methods. Scientists are consistently developing virtual systems of education, one of which involves a management system termed as the learning management system (LMS). The developers of this system wanted to make something that was educative and smart in order to meet the changing needs of learners and educators. However, the greatest challenge came with the need to define the system, how intelligent the system could be, the tools necessary to make it, and the system's composition and features [10]. Another question was how the LMS could be integrated and used together with mobile learning. The possibilities of this integration have been discussed in detail, and the challenges thereafter will also be discussed. There are different types of LMS with different degrees of intelligence and smartness as measured by various measurement models [11].

\section{B. Definition}

Unlike other teaching techniques, LMS gives teachers the opportunity to set examination questions in a more systematic manner. For instance, the teacher can design true or false questions or high-quality multiple-choice questions and still be able to connect them with the objectives to be achieved by the course [12]. LMSs are used to bring together collaborative and interactive aspects of a learning environment. This needs the developer to investigate the profiles of learners and use them to gain maximum feedback towards effective implementation of the LMS [13]. Most management systems are currently working towards adopting an LMS and considering the implications of adopting various LMS types in their regular practices. However, just like with mobile learning, most people are still not aware of the importance of 
LMSs, and the few that know about it have no idea of how best to integrate this knowledge in their daily operation. This has led to the development of various support systems that will ensure an appropriate system is adopted by the given institution. The major drive is the fact that both teachers and students need improved performance and a quicker growth in terms of education [14].

\section{Integrating Mobile Learning with LMSs}

This pertains to the process of applying learning management tools in a mobile learning environment. It requires that one fully understand the features of a mobile learning environment and match them with those of an intended LMS, for instance, integrating 'micro lectures' with mobile learning [15]. Any combination of an LMS with mobile learning gives rise to a new substance. In the above-mentioned integration, the resulting tool is a micro learning device which encourages the use of mobile terminals in learning. The combination of mobile learning and an LMS also results in a totally different system known as a mobile learning system. Such a system enables students and teachers to access learning materials from their personal computers and smartphones. The system is said to be effective, since various platforms can be used at the same time. The system integrates the development of androids, annotation of videos, analysis of how clustering takes place, push intelligence, identification of speech, Lucien full-text search, and other useful inventories. The use of different platforms ensures that students and teachers interact from any place and at any time they want, since resources can be shared even across long distances.

Various activities and occurrences also support the integration of mobile learning in teacher education settings. The technology applied is therefore referred to as distance learning. For instance, teachers can gain access to teaching modules, issue assignments and lectures to students, and receive feedback for all tasks assigned to long distance learners due to the availability of better communication devices. The system enables students to engage more in the learning process, as it is interesting, unconstrained by time limits, offers great comfort, and encourages performance and evaluation statistics. Such a system is therefore more effective in impacting knowledge and implementing the school curriculum than traditional methods of learning.

Similarly, integration allows for learning flexibility when there are too many requirements for learning. Traditionally, a single LMS is responsible for generation and management, and also for course and content delivery. Since most of such systems are not compatible with each other, there is a need for the development of many different systems with different functionality. Such systems allow learners to work on only what they want and get rid of that which they dislike [16], [17].

Another way of integration is the use of mobile devices that are integrated with Moodle LMSs. This combination increases the ability of students to handle the technical possibilities of incorporating activities of mobile learning in the process of electronic learning.

The integration also enables the use of an application interface that has been tied to different kinds of mobile devices that are geared towards the so called 'mainstreaming' of all mobile technologies in electronic learning [18].

\section{Methodology}

A total of 93 students, 40 males, and 43 females aged 18-21, from Nora University, Qassim University, and King Abdul-Aziz University from Saudi Arabia participated in this study. The method of sampling used was stratified random sampling. Participants were chosen from extracted name lists in accordance with the active involvement of the members in the assigned group. The students were familiar with m-learning settings from an earlier case study. They had to complete an open-ended questionnaire that asked for their opinion on their aptitude with regard to using m-learning in teaching and learning in Saudi Arabia.

A questionnaire comprising three pivots and 20 questions was distributed to participants. The first pivot, Individual Impacts, was concerned with how m-learning influences one's individual performance. The second pivot, Information Quality, was concerned with the relevance, timeliness, and format of reports, and the accuracy of the information generated by m-learning systems. The third pivot, Satisfaction, was a subjective evaluation of the various consequences of m-learning. The questionnaires were distributed to the 93 participants. Chi-Square $\left(\mathrm{x}^{2}\right)$ was used to analyse the data and comparing the distinction between frequency (f) and expected frequency (fe) around the phrases of the questionnaire.

\section{RESULTS}

\section{A. Category $A$}

Individual Impacts are concerned with how m-learning influences individual performance. This section sought to assess whether m-learning enhanced students' ability to interpret information accurately, better understand information and work-related activities at their university, make effective decisions, and increase overall productivity

TABLE I: $F, P, M, \mathrm{SD}, X^{2}$ VALUES, FOR STUDENT' ATtITUDES TOWARDS THE EFFECT OF USE M-LEARNING (CATEGORY A: INDIVIDUAL IMPACTS)

\begin{tabular}{llllll}
\hline \hline$N$ & \multicolumn{1}{c}{ Items } & $M$ & SD & $X^{2}$ & Sig. \\
\hline 1 & $\begin{array}{l}\text { I have learnt much through the } \\
\text { presence of m-learning. }\end{array}$ & 3.74 & 1.3 & 78.7 & $0.00^{* *}$ \\
2 & $\begin{array}{l}\text { M-learning enhances my } \\
\text { awareness and recall of job } \\
\text { related information } \\
3\end{array}$ & 3.97 & 1.3 & 104.3 & $0.00^{* *}$ \\
& $\begin{array}{l}\text { M-learning enhances my } \\
\text { effectiveness in the study } \\
\text { M-learning increases my } \\
\text { productivity }\end{array}$ & 3.75 & 1.3 & 61.1 & $0.00^{* *}$ \\
\hline \hline
\end{tabular}

As show in Table I and Fig. 1, that the $X^{2}$ value of all phrases concerned with students' view points and attitudes towards the effect of m-learning use (Category A: Individual Impacts) is greater than the $X^{2}(4, N=93)=7.08, p=.05$. This indicates that the distinction between the frequencies $(f)$ and the expected frequency $(f e)$ around the phrases concerned with the Individual Impacts pivot is statistically significant and does not, therefore, go back to the chance factor. The distinction between students' approval or disapproval of the 
phrases of the questionnaire is in favour of student' attitudes towards the effect of the teacher's performance on student anxiety.

In other words, these students learnt a lot through the presence of m-learning because they felt relaxed and comfortable in the English classes. Additionally, they made progress in the English classes and were able to participate in the classes, and they showed a positive attitude toward their English teacher. The results indicate the existence of a statistical difference between the mean of students' attitudes towards the effect of teacher's performance on students' anxiety. The results also indicate the following:

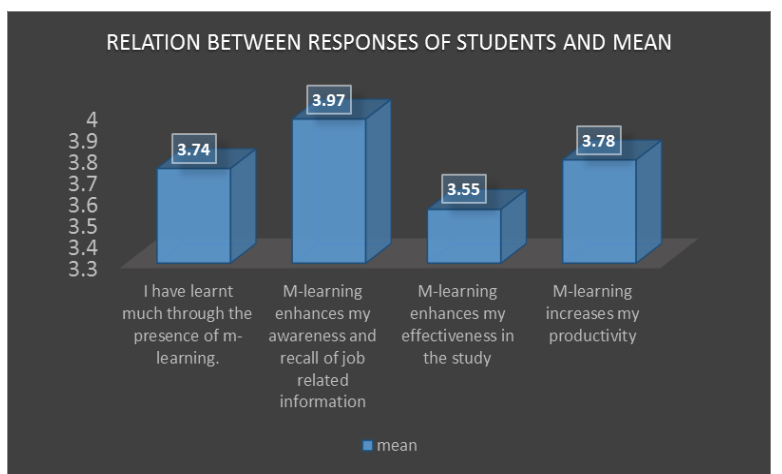

Fig. 1. The relation between responses of students and mean.

TABLE II: $F, P, M$, SD, AND $\mathrm{X}^{2}$ VALUES FOR STUDENTS' ATTITUDES TOWARDS THE EFFECT OF USE OF M-LEARNING (CATEGORY B: INFORMATION QUALITY)

\begin{tabular}{|c|c|c|c|c|c|}
\hline$N$ & Items & $M$ & SD & $X^{2}$ & Sig. \\
\hline 5 & $\begin{array}{l}\text { Information available from } \\
\text { M-learning is important }\end{array}$ & 4.14 & 1.157 & 76.7 & $0.00^{\text {** }}$ \\
\hline 6 & $\begin{array}{l}\text { M-learning provides output } \\
\text { that seems to be exactly } \\
\text { what is needed }\end{array}$ & 4.08 & .875 & $59.312^{\mathrm{a}}$ & $0.00^{* * *}$ \\
\hline 7 & $\begin{array}{l}\text { Information needed from } \\
\text { m-learning is always } \\
\text { available }\end{array}$ & 4.09 & .922 & 57.02 & $0.00^{* *}$ \\
\hline 8 & $\begin{array}{l}\text { Information from } \\
\mathrm{m} \text {-learning is in a form that } \\
\text { is readily usable }\end{array}$ & 4.30 & 1.019 & 103.8 & $0.00^{* *}$ \\
\hline 9 & $\begin{array}{l}\text { Information from } \\
\text { m-learning is easy to } \\
\text { understand }\end{array}$ & 4.25 & 1.039 & 90.15 & $0.00^{* * *}$ \\
\hline 10 & $\begin{array}{l}\text { Information from } \\
\text { m-learning appears } \\
\text { readable, clear and well } \\
\text { formatted }\end{array}$ & 4.08 & 1.296 & 90.49 & $0.00^{* * *}$ \\
\hline 11 & $\begin{array}{l}\text { Though data from } \\
\text { m-learning may be } \\
\text { accurate, outputs } \\
\text { sometimes are not }\end{array}$ & 4.25 & 1.274 & 133.07 & $0.00^{* *}$ \\
\hline 12 & $\begin{array}{l}\text { Information from } \\
\mathrm{m} \text {-learning is concise }\end{array}$ & 4.80 & .501 & 241.4 & $0.00^{* * *}$ \\
\hline 13 & $\begin{array}{l}\text { Information from } \\
\text { m-learning is always timely }\end{array}$ & 4.57 & .786 & 160.8 & $0.00^{* *}$ \\
\hline 14 & $\begin{array}{l}\text { Information from } \\
\text { m-learning is unavailable } \\
\text { elsewhere }\end{array}$ & 4.63 & .987 & 238.1 & $0.00^{* *}$ \\
\hline
\end{tabular}

- Phrase no. 1 indicates that 48 students (51.6\%) confirmed that they had learnt a lot through the presence of m-learning.

- Phrase no. 2 shows that 55 students $(59.1 \%)$ ensured that m-learning enhanced their awareness and recall of job-related information.

- Phrase no. 3 shows that 40 students $(43.0 \%)$ ensured that m-learning enhanced their effectiveness in the study.
- Phrase no. 4 indicates that 55 students (55.9\%) emphasized that m-learning increased their productivity.

\section{B. Category $B$}

Information Quality is concerned with the relevance, timeliness, and format of reports, and the accuracy of information generated by the m-learning system. Here, the focus is on the quality of m-learning outputs: namely, the quality of the information the system produces in reports and on-screen.

In Table II and Fig. 2, that the $X^{2}$ value of all phrases concerned with the students' attitudes towards the effect of m-learning use (Category B: Information Quality) is greater than the $X^{2}(4, N=93)=7.08, p=.05$. This indicates that the distinction between frequencies (f) and the expected frequency (fe) around the phrases concerned with that pivot is statistically significant, and it does not, therefore, go back to the chance factor. The distinction between students' approval or disapproval of the phrases of the questionnaire is in favour of students attitudes towards the effect of the teacher's performance on student anxiety.

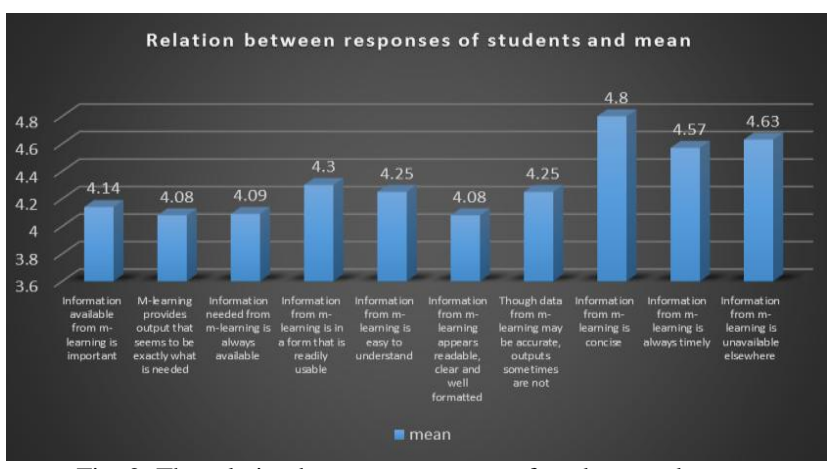

Fig. 2. The relation between responses of students and mean.

The students' responses indicate the following:

Phrase no. 5 indicates that 50 students $(51.6 \%)$ confirmed that the information gained from m-learning is important.

1) Phrase no. 6 shows that (37) students (39.8\%) ensured that m-learning provided outputs that seem to be exactly what are needed.

2) Phrase no. 7 showsthat (39) students (41.9\%) ensured that the information needed from m-learning was always available.

3) Phrase no. 8 indicates that (56) students (60.2\%) emphasized that the information from m-learning was in a form that was readily usable.

4) Phrase no. 9 indicates that (52) students (55.9\%) confirmed that the information from m-learning was easy to understand.

5) Phrase no. 10 shows that (55) students (59.1) ensured that the information from m-learning appeared readable, clear, and well formatted.

6) Phrase no. 11 shows that (63) students (67.7\%) ensured that although data from m-learning may be accurate, outputs sometimes are not.

7) Phrase no. 12 indicates that (78) students (83.9\%) emphasized that information from m-learning was concise.

8) Phrase no. 13 shows that (66) students (71.0) ensured that the information from m-learning was always timely. 
9) Phrase no. 14 indicates that (78) students (83.9\%) emphasized that the information from m-learning was unavailable elsewhere.

\section{Category $C$}

Satisfaction is a subjective evaluation of the various consequences of m-learning.

TABLE III: $F, P, M, \mathrm{SD}, X^{2}$ VALUES, FOR STUdENT' ATtITUdES TOWARdS THE SUBJECTIVE EVALUATION OF THE VARIOUS CONSEQUENCES OF

\begin{tabular}{|c|c|c|c|c|c|}
\hline \multicolumn{6}{|c|}{ M-LEARNING (CATEGORY E: SATISFACTION) } \\
\hline$\frac{N}{15}$ & Overall the m-learning & $\frac{M}{425}$ & $\frac{\mathrm{SD}}{1148}$ & $X$ & $\frac{\text { Sig. }}{000^{* *}}$ \\
\hline 15 & $\begin{array}{l}\text { Overall, the m-learning } \\
\text { System Quality is } \\
\text { satisfactory }\end{array}$ & 4.25 & 1.148 & 101.1 & \\
\hline 16 & $\begin{array}{l}\text { Overall, the m-learning } \\
\text { Information Quality is } \\
\text { satisfactory }\end{array}$ & 4.15 & .966 & 68.3 & $0.00^{* *}$ \\
\hline 17 & $\begin{array}{l}\text { M-learning is enjoyable } \\
\text { to use }\end{array}$ & 4.23 & .990 & 78.7 & $0.00^{* *}$ \\
\hline 18 & $\begin{array}{l}\text { Overall, m-learning is } \\
\text { satisfactory }\end{array}$ & 4.48 & .974 & 160.6 & $0.00^{* * *}$ \\
\hline 19 & $\begin{array}{l}\text { The impact of } \\
\text { m-learning on the } \\
\text { education has been } \\
\text { positive. }\end{array}$ & 4.30 & 1.035 & 105.2 & $0.00^{* *}$ \\
\hline 20 & $\begin{array}{l}\text { The impact of } \\
\text { m-learning on } \underline{m e} \text { has } \\
\text { been positive. }\end{array}$ & 4.16 & 1.321 & 115.4 & $0.00^{* * *}$ \\
\hline
\end{tabular}

In Table III and Fig. 3 shows that the $X^{2}$ value of all phrases concerned with the students' view points on students' attitudes towards the effect of use m-learning (Category $\mathrm{C}$ : Satisfaction) is bigger than the $X^{2}(4, N=93)=7.08, \mathrm{p}=.05$. This indicates that the distinction between the frequencies ( $f$ ) and the expected frequency (fe) around the phrases concerned with that pivot is statistically significant and it does not, therefore, go back to the chance factor. The distinction between students' approval or disapproval of the phrases of the questionnaire is in favour of students' attitudes towards the effect of the teacher's performance on student' anxiety.

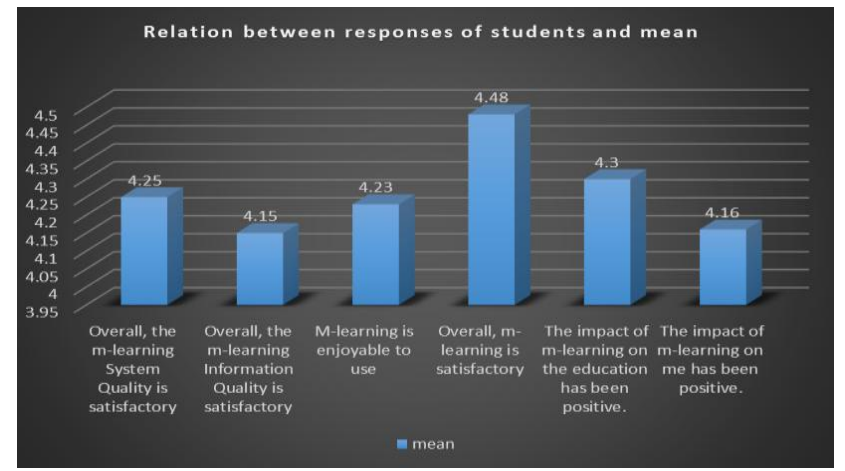

Fig. 3. Shows the relation between responses of students and mean.

Thus, the students ensured that the m-learning system quality is satisfactory. They emphasized that the m-learning information quality was satisfactory. They ensured that the impact of m-learning on the education was positive. They showed that the impact of m-learning was positive. The results indicate the existence of statistical differences between the mean of students' attitudes towards the effect of the teacher's performance on student' anxiety. The results also indicate the following:

- Phrase no. 15 indicates that (56) students $(60.2 \%)$ confirmed that the m-learning system quality was satisfactory.

- Phrase no. 16 shows that (44) students (47.3\%) ensured that the m-learning information quality was satisfactory

- The (phrase no.17) shows that (48) students (51.6\%) ensured that m-learning was enjoyable to use.

- Phrase no. 18 indicates that (67) students (72.0\%) emphasized that overall, m-learning is satisfactory.

- Phrase no. 19 indicates that (56) students (60.2\%) confirmed that the impact of m-learning on education was positive.

- Phrase no. 20 shows that (60) students (59.1\%) believed that the impact of m-learning on themselves was positive.

\section{CONCLUSION}

The purpose of this qualitative research was to examine students' attitude towards the use of m-learning in teaching and learning in Saudi Arabia. At the end of the study, the participating students had to complete a questionnaire based on their experiences with the mobile learning application used in the study. The students' opinions on mobile learning were essential to the evaluation of this method of learning and teaching.

The majority of the students who participated in the three evaluation studies generally responded positively to the use of m-learning in teaching and learning in Saudi Arabia. The students came from many universities throughout Saudi Arabia. This m-learning study is the first of its kind in Saudi Arabia and. However, more development and experimentation is required.

\section{REFERENCES}

[1] W. A. Abu-Dawwas, "A new scoring method for multiple choice test in learning management systems," International Journal of Academic Research, vol. 6, no. 1, pp. 274-280, September 2015.

[2] E. Baran, "A review of research on mobile learning in teacher education," Journal of Educational Technology \& Society, vol. 17, no. 4, pp. 17-32, 2014

[3] Z. Bogdanović, D. Barać et al., "Evaluation of mobile assessment in a learning management system," British Journal of Educational Technology, vol. 45, no. 2, pp. 231-244, 2014.

[4] A. Butoi, N. Tomai, and L. Mocean, "Cloud-based mobile learning', informatica economica," Business Source Complete, Ebscohost, vol 17, no. 2, pp. 27-40, 2013.

[5] N. Cavus, "Selecting a learning management system (LMS) in developing countries: Instructors' evaluation," Interactive Learning Environments, vol. 21, no. 5, pp. 419-437, Academic Search Premier, Ebscohost, 2013.

[6] T. Chiang, S. Yang, and G. Hwang, "An augmented reality-based mobile learning system to improve students' learning achievements and motivations in natural science inquiry activities," Journal of Educational Technology \& Society, vol. 17, no. 4, pp. 352-365, Academic Search Premier, EBSCOhost, 2014.

[7] S. Dias and J. Diniz, "Towards an enhanced learning management system for blended learning in higher education incorporating distinct learners' profiles," Journal of Educational Technology \& Society, vol 17, no. 1, pp. 307-319, Academic Search Premier, EBSCOhost, 2014.

[8] A. Fardinpour, M. Pedram, and M. Burkle, "Intelligent learning management systems: Definition, features and measurement of intelligence," International Journal of Distance Education Technologies, vol. 12, no. 4, pp. 19-31, Business Source Complete, EBSCOhost, 2014

[9] G. Gutiérrez-Carreón, T. Daradoumis, and J. Jorba, "Integrating learning services in the cloud: An approach that benefits both systems and learning," Journal of Educational Technology \& Society, vol. 18, no. 1, pp. 145-157, Academic Search Premier, EBSCOhost, 2015.

[10] C. Hui-Chun, "Potential negative effects of mobile learning on students' learning achievement and cognitive load — A forma 
assessment perspective," Journal of Educational Technology \& Society, vol. 17, no. 1, pp. 332-344, Academic Search Premier, EBSCOhost, 2014.

[11] E. Kaganer, G. Giordano, S. Brion, and M. Tortoriello, "Media tablets for mobile learning," Communications of the ACM, vol. 56, no. 11, pp. 68-75, Business Source Complete, Ebscohost, 2013.

[12] D. Keller, "PART 3: A whole new LMS world," Training, vol. 52, no. 2, pp. 36-37, Business Source Complete, EBSCOhost, 2015.

[13] B. Lochner, R. Conrad, and E. Graham, "Secondary teachers' concerns in adopting learning management systems: A U.S. perspective," Techtrends: Linking Research \& Practice To Improve Learning, vol. 59, no. 5, pp. 62-70, Academic Search Premier, EBSCOhost, 2015.

[14] M. Nabipour, "The impact of mobile learning on learning and retention chemistry and providing an educational design model," International Journal of Academic Research, vol. 7, no. 1, pp. 554-560, Academic Search Premier, EBSCOhost, 2015.

[15] P. Pocatilu, A. Visoiu, M. Doinea, and W. Osch, "Mobile learning and mobile technologies in academia: a case study," Economic Computation \& Economic Cybernetics Studies \& Research, vol. 46, no. 3, pp. 79-98, Business Source Complete, EBSCOhost, 2012.

[16] W. Rodriguez, N. Nguyen-Huynh, A. Fernandez, J. Royal, and V. Fernandez, "Developing a mobile learning environment: An Axiomatic approach," Journal of International Technology \& Information Management, vol. 23, no. 3/4, pp. 45-60, Business Source Complete, EBSCOhost, 2014.

[17] Ş. S. Nihat and Ö. Göktaş, 'Preservice teachers' perceptions about using mobile phones and laptops in education as mobile learning tools," British Journal of Educational Technology, vol. 45, no. 4, pp. 606-618, Academic Search Premier, EBSCOhost, 2014.
[18] C. Wen and J. Zhang, Design of a microlecture mobile learning system based on smartphone and web platforms," IEEE Transactions on Education, vol. 58, no. 3, pp. 203-207, Business Source Complete, EBSCOhost, 2015.

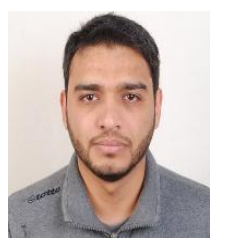

Salem Alkhalaf was born in Alrass city, Kingdom of Saudi Arabia. He is an assistant professor in Computer Department, College of Science and Arts in Al-Rass, Qassim University. He graduated with the bachelor of education degree in computer Since from the Department of Computer, Teachers College (Riyadh) in 2003. Also he graduated with honors degree. And he graduated the master of ICT from Griffith University (Brisbane, Australia) in 2008. And, he graduated the $\mathrm{PhD}$ in ICT from Griffith University (Gold Coast, Australia). Finally, he is interest developing e-learning environments for universities especially in KSA.

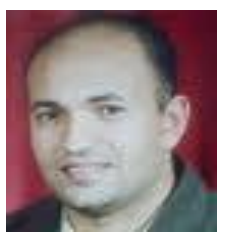

Mohamed Amasha was born in Egypt, Domyat, in 1970. He is associate professor in the application of computer in education, Domyat University Egypt, Qassim University Saudi Arabia 2012. He works as lecturer, associate professor in Qassim University. He has published in A.U.C in Egypt, IJACSA, IJORCS.

Amal Al-Jarallah is associate professor in educational technology, Princess Nourah Bint Abdulrahman University, Saudi Arabia 2012. She works as lecturer, associate professor in Princess Nourah Bint Abdulrahman University. She has published in educational technology field. 